\title{
Influence of Brazilian pine seed flour addition on rheological, chemical and sensory properties of gluten-free rice flour cakes
}

\author{
Mônica Ikeda ${ }^{1}$ Carlos Wanderlei Piler Carvalho ${ }^{2}$ Cristiane Vieira Helm ${ }^{3}$ \\ Henriette Monteiro Cordeiro de Azeredo ${ }^{4,5}$ Rossana Catie Bueno de Gogoy ${ }^{3}$ \\ Rosemary Hoffmann Ribani ${ }^{1 *}$
}

\footnotetext{
${ }^{1}$ Programa de Pós-graduação em Engenharia de Alimentos, Universidade Federal do Paraná (UFPR), 821531-980, Curitiba, PR, Brasil. E-mail: ribani@ufpr.br. "Corresponding author.

${ }^{2}$ Embrapa Agroindústria de Alimentos, Empresa Brasileira de Pesquisa Agropecuária, Rio de Janeiro, RJ, Brasil.

${ }^{3}$ Embrapa Florestas, Empresa Brasileira de Pesquisa Agropecuária, Colombo, PR, Brasil.

${ }^{4}$ Embrapa Agroindústria Tropical, Empresa Brasileira de Pesquisa Agropecuária, Fortaleza, CE, Brasil.

${ }^{5}$ Embrapa Instrumentação, São Carlos, SP, Brasil.
}

ABSTRACT: Brazilian pine seeds (pinhão) are gluten-free seeds produced by the native pine species named Araucaria angustifolia. In this study, gluten-free cake mixes composed of Brazilian pine seed flour and rice flour were developed. The cake mixes were produced following a Simplex Centroid experimental design, with rice flour and Brazilian pine seed flour contents ranging from 50 to $100 \%$ and from 0 to $50 \%$, respectively. Mixes were analyzed for chemical composition, apparent paste viscosity, and particle size distribution. The resulting cakes were analyzed for sensory acceptance, texture, specific volume and chemical composition. The Brazilian pine seed flour showed a peak viscosity on heating of 1.761Pa.s against 4.747Pa.s for the 100\% rice flour sample. The variation of firmness of cakes decreased with increasing percentage of Brazilian pine seed flour. Cakes containing Brazilian pine seed flour at 25-37.5\% of the formulation presented highest overall acceptance. Key words: Araucaria angustifolia, celiac, sensory, cake, rheology.

Influência da adição de farinha de pinhão sobre as propriedades reológicas, químicas e sensoriais de bolos sem glúten produzidos com farinha de arroz

RESUMO: O pinhão trata-se de uma semente sem glúten, produzida pelo pinheiro da espécie Araucaria angustifolia. Neste estudo, foram desenvolvidas misturas de bolo sem glúten, compostas por farinha de pinhão e farinha de arroz. As misturas de bolo foram produzidas conforme o modelo experimental Simplex Centroid, que definiu as proporções entre a farinha de arroz e a farinha de pinhão na variação de 50 a 100\% e 0 a 50\%, respectivamente. As misturas foram analisadas quanto à composição química, viscosidade aparente da pasta e distribuição de tamanho de partícula. Os bolos resultantes foram submetidos às análises de aceitação sensorial, textura volume especifico e composição química. A farinha de pinhão demostrou ocorrência do pico de viscosidade ao aquecimento no valor de 1,761Pa.s contra 4,747Pa.s da amostra composta por $100 \%$ de farinha de arroz. A variação da firmeza dos bolos diminuiu com o aumento da porcentagem de farinha de pinhão. Em termos sensoriais, os bolos contendo entre 25 a 37,5\% de farinha de pinhão apresentaram maior aceitação geral.

Palavras-chave: Araucaria angustifolia, fibradietética, celiaco, sensorial, bolo, reologia.

\section{INTRODUCTION}

Reflecting the current concerns with health and the best scientific understanding of certain eating disorders, there has been a growing commercial interest for differentiated products for people with specific dietary requirements. The intake of cereals containing gluten affects the small intestine of people with celiac disease, which is a chronic inflammation of the digestive system in genetically predisposed individuals, characterized by malabsorption of nutrients with consequent body's immunity deficiency. The usual treatment is limited to gluten exclusion from diet (RUBIOTAPIA et al, 2009).

Research on development of glutenfree products has increased. JAN et al. (2016) produced gluten-free cookies from flour of either raw or sprouted Chenopodium album; MORAIS et al. (2014) developed prebiotic gluten-free bread, and GORGÔNIO et al. (2011) produced a glutenfree cake added with fibers and no sugar. The focus is on products requiring little technology, and the concern with sensory quality is often 
minimized. Thus, the celiac consumers face not only high costs for those differentiated products, but also a low variety of nutritionally and sensorialpoor products (MARIOTTI et al, 2008). New alternatives of cake mixes may be attractive for celiac people. Pre-mixes can be commercially advantageous, since they require less space for storage, besides having longer shelf life than finished products (RAMOS et al, 2012).

Rice flour is the most used ingredient in gluten-free products, since rice is hypoallergenic, colorless, and well accepted. Another gluten-free alternative is the flour produced from Brazilian pine seeds, whose composition displays a considerable dietary fiber content and low glycemic index (CAPELLA, 2008). The application of this flour not only adds value to the seed, which is barely explored by industries, but also may promote preservation of Araucaria angustifolia. In addition, the Brazilian pine seed has high nutritive value and fiber properties due to the resistant starch composition. Thus, the seed has a low glycemic index, relating its consumption to the reduction of type 2 diabetes. The bark is rich in phenolic and mineral compounds, which are absorbed by the seed during the heat treatment. (ALONSO \& MORAGA, 2014). This study aimed to evaluate the incorporation of different contents of Brazilian pine seed flour into rice flour based-cake mixes destined for celiac patients.

\section{MATERIALS AND METHODS}

Seeds of Araucaria angustifolia provided by Embrapa Florestas (Colombo, PR, Brazil) were used in the preparation of Brazilian pine seed flour (BPSF) according to the procedure described in the Technical Report of Embrapa Florestas (CORNEJO et al, 2014), where the seeds were subjected to desquamation, followed by drying, with a temperature between $50^{\circ} \mathrm{C}$ and $60^{\circ} \mathrm{C}$ under a minimum air flow of $0.5 \mathrm{~m} / \mathrm{s}$, during 18 to 24 hours, reaching the moisture content between 3.5 to $5.0 \%$. Then, the seeds were ground in a knife and hammer mill, with a $2 \mathrm{~mm}$ opening sieve to obtain the flour. Rice flour was provided by Reunidas Coringa (Arapiraca, AL, Brazil).

The blends of BPSF and rice flour were prepared according to a Simplex Centroid experimental design. Five flour blends were prepared with the following rice flour: BPSF weight ratios: $100: 0 ; 50: 50 ; 75: 25 ; 87.5: 12.5$ and 62.5:37.5. Blends were prepared by using the Geiger GUM/
SK 130E homogenizer(Geiger Machinery Industry, Pinhais, PR, Brazil).

The dry components were firstly mixed, the $450 \mathrm{~g}$ - dry mixture being composed of $46 \%$ flour blend, $42 \%$ sucrose, $0.3 \%$ salt, $5 \%$ fat, $2 \%$ emulsifier (monoglyceride and diglyceride), $2 \%$ baking powder, $2 \%$ corn starch, $0.5 \%$ calcium propionate, $0.2 \%$ flavoring agent (vanilla flavor), $0.05 \%$ carboxymethylcellulose and $0.05 \%$ hydroxypropylmethylcellulose. Dry mixture was then homogenized with the remaining ingredients ( $150 \mathrm{~mL}$ milk, 3 whole eggs, and $40 \mathrm{~g}$ butter) for $2 \mathrm{~min}$ in a planetary mixer SX84 (Arno, São Paulo, Brazil) at low speed (8500-9500rpm) and then for 3 minutes at high speed (14500-16500rpm).

Portions of $250 \mathrm{~g}$ were put into trays $(0.11 \mathrm{~m} \mathrm{X} 0.24 \mathrm{~m} \mathrm{X} 0.045 \mathrm{~m})$, previously greased and sprinkled with rice flour. Doughs were baked in an FP3 oven (HAAS Brazil Machinery Industry, Curitiba, Brazil) for 25 minutes at $200^{\circ} \mathrm{C}$. Baked cakes were cooled to $22^{\circ} \mathrm{C}$ and removed from the trays. Cakes (Figure 1) were stored in polypropylene packaging at $22^{\circ} \mathrm{C}$ and $80-85 \% \mathrm{RH}$. Except for the BPSF, all ingredients and equipment were provided by Granolab Granotec Brazil (Curitiba, PR, Brazil).

The rice flour:BPSF blends were analyzed for chemical composition using the following methods (AACC, 2000): moisture content (44-31), ashes (08-12), proteins (46-13A), lipids (30-26) and dietary fiber (32-07). Total carbohydrates were calculated by difference.

The apparent paste viscosity was determined with a Rapid ViscoAnalyser4500 (Perten Instruments, Warriewood, Australia) following the method AACC 76-21. Particle size was determined by the method AACC 66-20 in a sieve shaker (Ro-tap, Telastem, São Paulo, Brazil). Cakes were evaluated for chemical composition and texture (firmness and extensibility) (AACC method 74-09), the latter using a texturometer TA-XT2 (Stable Micro System, Surrey, UK) provided with a $0.025 \mathrm{~m}$ cylindrical probe. Cakes were submitted to the analysis of specific volume $(\mathrm{g} /$ $\mathrm{cm}^{3}$ ) from the method AACC 72-10 in an Vondel VDMV-23/MVP 4000 equipment.

The sensory properties of cakes were assessed using a semi-structured questionnaire to obtain information on gender, age, education level, frequency of consumption, purchase requirement and health of the participants (FERREIRA et al, 2000). The sensory panel consisted of 102 untrained panelists - most of them graduate students -, composed of $53.92 \%$ men and $46.08 \%$ women aged between 26 and 35 years. All panelists reported a 


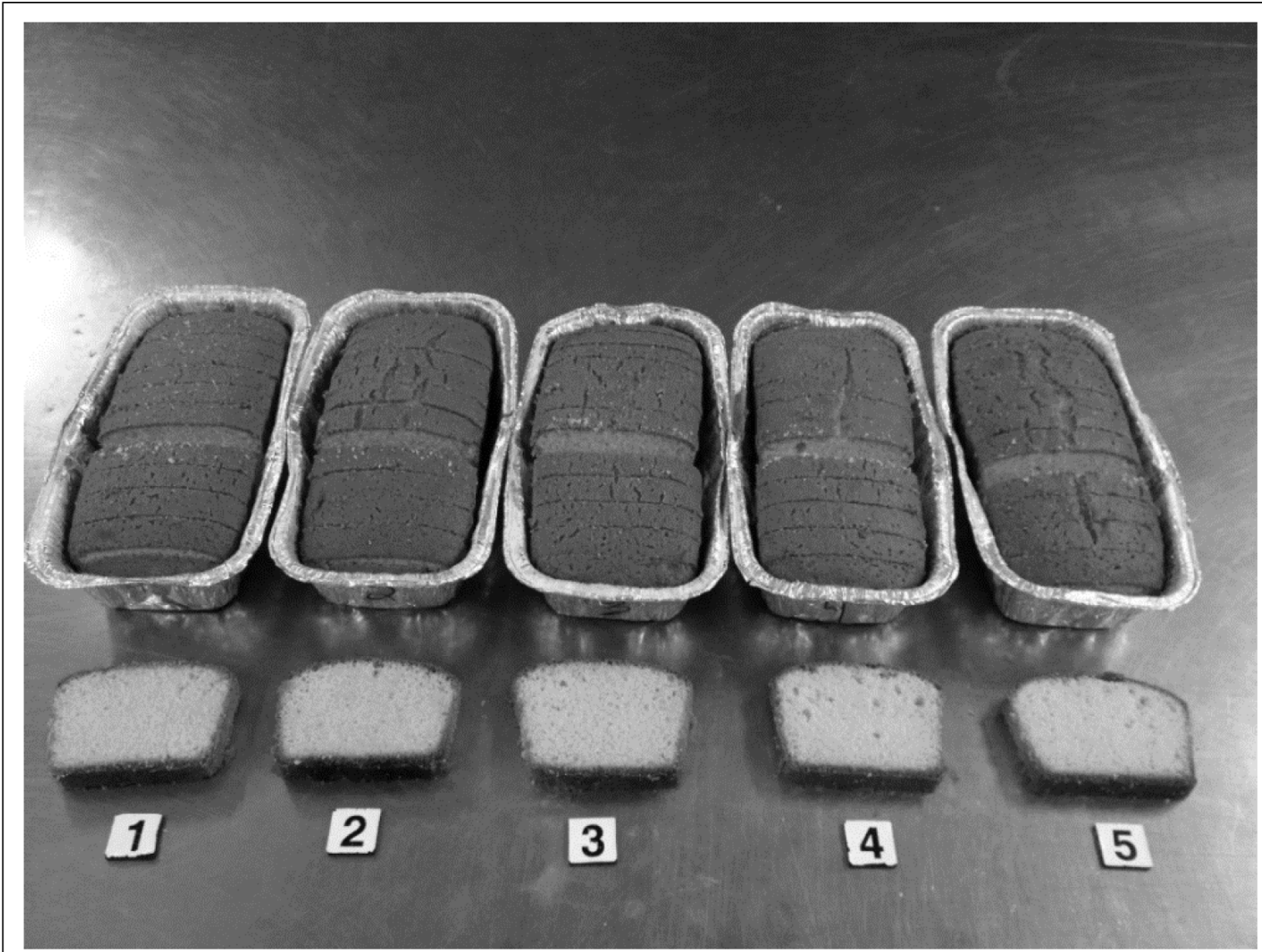

Figure 1 - Cakes sorted according to treatment under evaluation: 1 (100\% rice flour x $0 \%$ Brazilian pine seeds flour); 2 (50\% rice flour $\mathrm{x}$ $50 \%$ Brazilian pine seeds flour); 3 (75.0\% rice flour x 25.0\% Brazilian pine seeds flour); 4 (87.5\% rice flour x 12.5\% Brazilian pine seeds flour); 5 (62.5\% rice flour x $37.5 \%$ Brazilian pine seeds flour).

usual weekly consumption of cake. For each sample, participants were asked to rate their overall liking and intensity of crumbliness. Liking was assessed using a standard 9-point hedonic scale ( $1=$ "Extremely disliked", 5 = "Neither Like Nor Dislike", and 9 $=$ "Extremely liked") according to PERYAM \& PILGRIM (1957). Crumbliness was evaluated using a 5-point just-about-right scale (JAR), being1 "very crumbly", 3 "ideal", and 5 "very crumbly" (LI et al, 2014). The order of presentation followed a completely balanced design (MACFIE et al, 1989) to avoid carryover effects. Consumers received approximately $60 \mathrm{~g}$ of each cake, coded with random three-digit numbers in a monadic way, and were instructed to drink water between samples. The samples differ in the ratio of rice flour and Brazilian pine seeds flour. Each ratio was randomly coded to be subjected to sensory tests (Table 1).

Table 1 - Sample codes and ratios between the rice flour and Brazilian pine seeds flour.

\begin{tabular}{lccccc}
\hline Sample code & 196 & 466 & 305 & 532 & 278 \\
Rice flour: Brazilian pine seeds flour ratio & $100: 0$ & $87.5: 12.5$ & $75: 25$ & $62.5: 37.5$ & $50: 50$
\end{tabular}

Ciência Rural, v.48, n.6, 2018. 
The centesimal composition and rheological properties of flour blends and cakes were statistically treated by the Simplex Centroid model. Data from the treatments were compared by analysis of variance (ANOVA) and Tukey test at 5\% confidence level.

The sensory acceptance results were analyzed by multivariate techniques, such as the Principal Component Analysis (PCA) and the Hierarchic Aglomerative Analysis (HAA), using the statistical software XLSTAT- Sensory (2014). Data from JAR scale was calculated by summing the number of answers for each category.

\section{RESULTS AND DISCUSSION}

According to table 2, the rice flour presented lower fiber content than the other flour blends $(\mathrm{P} \leq 0.05)$. Thus, the addition of BPSF increased the dietary fiber content in the flour blends. According to RDC 54/2012 (BRAZIL, 2012 ), in a $50 \mathrm{~g}$ portion of flour described in RDC $359 / 2003$ (BRAZIL, 2003) are necessary $2.5 \mathrm{~g}$ of fiber to achieve the claim of "fiber source". For the proportion composed of $50 \% \mathrm{BPSF}$, it was identified the amount of $3.86 \mathrm{~g}$ of fiber in the blend, consequently, considered as a source of fibers. The protein contents of BPSF or blends containing it were similar to that of whole rice flour, but lower when compared to the other flours evaluated by AUGUSTO-RUIZ et al. (2003). Dietary fiber contents of the blends containing BPSF were similar to whole rice flour, higher than wheat flour and lower than oatmeal. Conversely, the pure BPSF presented dietary fiber content similar to that of whole grains, as in the case of brown rice and oat flour. Furthermore, the flours prepared with BPSF (in any weight ratio) resulted in considerable lower lipid content compared to oat flour.

Based on the apparent viscosity parameters (Table 3), the blend with higher proportion of BPSF (50\%) showed a lower final viscosity (3.510 $\pm 0.126 \mathrm{~Pa}$.s) when compared to $100 \%$ rice flour $(7.706 \pm 0.237 \mathrm{~Pa} . \mathrm{s})$. In addition, the tendency to starch retrogradation by BPSF was lower (1.761 $\pm 0.510 \mathrm{~Pa} . \mathrm{s})$ when compared to that by rice flour (4.747 \pm 0.157 Pa.s). As confirmed by the Tukey test also for peak viscosity and minimal viscosity under heating, the differences indicated that the blends containing BPSF is likely to have a greater resistance to retrogradation, and consequently a longer physical stability.

The increased viscosity and the development of a rigid structure in products with starch occured during the retrogradation process (FENNEMA et al, 2010). Retrogradation in cakes shows negative impacts on their texture (DELCOUR et al, 2010). FERNG et al. (2016) compared cakes developed with three varieties of rice (long, short and glutinous, in decreasing order of apparent amylose content). The authors reported that the firmness of the ready fresh product was higher in the sample with lower apparent amylose content, confirming that the product containing

Table 2 - Chemical composition of rice flour and Brazilian pine seeds flour blends compared with other flours (Brazilian pine seeds, whole rice flour, oat flour and wheat flour).

\begin{tabular}{|c|c|c|c|c|c|c|}
\hline $\begin{array}{l}\text { Rice flour: Brazilian pine } \\
\text { seeds flour ratio }\end{array}$ & Moisture (g/100g) & Ashes $(g / 100 g)$ & $\begin{array}{l}\text { Total dietary } \\
\text { fiber }(g / 100 g)\end{array}$ & $\begin{array}{l}\text { Proteins } \\
(\mathrm{g} / 100 \mathrm{~g})\end{array}$ & Fats $(g / 100 g)$ & $\begin{array}{l}\text { Carbohydrates } \\
(\mathrm{g} / 100 \mathrm{~g})\end{array}$ \\
\hline 100:00 & $11.10^{\mathrm{a}}$ & $0.58^{\mathrm{cd}}$ & $4.27^{\mathrm{b}}$ & $7.49^{\mathrm{a}}$ & $1.23^{\mathrm{a}}$ & $75.33^{\mathrm{a}}$ \\
\hline $87.5: 12.5$ & $6.82^{\mathrm{b}}$ & $0.82^{\mathrm{d}}$ & $5.63^{\mathrm{ab}}$ & $7.45^{\mathrm{a}}$ & $1.62^{\mathrm{a}}$ & $77.67^{\mathrm{a}}$ \\
\hline $75: 25$ & $7.0^{\mathrm{b}}$ & $1.05^{\mathrm{bc}}$ & $6.78^{\mathrm{a}}$ & $7.33^{\mathrm{a}}$ & $2.01^{\mathrm{a}}$ & $75.82^{\mathrm{a}}$ \\
\hline $62.5: 37.5$ & $6.96^{\mathrm{b}}$ & $1.32^{\mathrm{b}}$ & $5.42^{\mathrm{ab}}$ & $7.41^{\mathrm{a}}$ & $1.74^{\mathrm{a}}$ & $77.14^{\mathrm{a}}$ \\
\hline $50: 50$ & $7.14^{\mathrm{b}}$ & $1.9^{\mathrm{a}}$ & $7.71^{\mathrm{a}}$ & $7.31^{\mathrm{a}}$ & $1.17^{\mathrm{a}}$ & $74.78^{\mathrm{a}}$ \\
\hline Brazilian pine seeds flour ${ }^{a}$ & 7.96 & 2.97 & 10.94 & 7.27 & 1.49 & 69.37 \\
\hline Whole rice flour ${ }^{\mathrm{a}}$ & 6.8 & 1.52 & 9.63 & 8.21 & 1.52 & 72.32 \\
\hline Oat flour ${ }^{\mathrm{b}}$ & 7.60 & 1.60 & 11.80 & 16.55 & 11.26 & 51.19 \\
\hline Wheat flour ${ }^{\mathrm{b}}$ & 12.60 & 0.47 & 2.26 & 10.0 & 0.67 & 74.0 \\
\hline
\end{tabular}

${ }^{\mathrm{a} D}$ Data from these authors (2015); ${ }^{\mathrm{b}}$ Data from Augusto-Ruiz et al (2003). 
Table 3 - Viscosity of composed of rice flour and Brazilian pine seeds flour blends.

\begin{tabular}{|c|c|c|c|c|c|}
\hline Blends & $100: 0$ & $87.5: 12.5$ & $75: 25$ & $62.5: 37.5$ & $50: 50$ \\
\hline \multicolumn{6}{|l|}{ - } \\
\hline Viscosity of Peak (Pa.s) & $4.05 \pm 0.37^{\mathrm{a}}$ & $3.85 \pm 0.37^{\mathrm{a}}$ & $3.34 \pm 0.40^{\mathrm{b}}$ & $2.89 \pm 0.17^{\mathrm{c}}$ & $2.87 \pm 0.12^{\mathrm{c}}$ \\
\hline Viscosity breakdown (Pa.s) & $2.96 \pm 0.81^{\mathrm{a}}$ & $2.79 \pm 0.80^{\mathrm{a}}$ & $2.25 \pm 0.68^{\mathrm{b}}$ & $1.99 \pm 0.28^{\mathrm{c}}$ & $1.75 \pm 0.82^{\mathrm{d}}$ \\
\hline Final viscosity (Pa.s) & $7.71 \pm 0.24^{\mathrm{a}}$ & $6.91 \pm 0.53^{b}$ & $5.50 \pm 0.51^{\mathrm{c}}$ & $4.39 \pm 0.15^{\mathrm{d}}$ & $3.51 \pm 0.13^{\mathrm{e}}$ \\
\hline Retrogradation tendency (Pa.s) & $4.75 \pm 0.16^{\mathrm{a}}$ & $4.12 \pm 0.12^{b}$ & $3.25 \pm 0.34^{\mathrm{c}}$ & $2.40 \pm 0.13^{\mathrm{d}}$ & $1.76 \pm 0.51^{\mathrm{e}}$ \\
\hline
\end{tabular}

Blends = Rice flour: Brazilian pine seeds flour weight ratio; Means followed by the same letter on the same line do not differ according to the Tukey test at $5 \%$ probability.

long rice flour (highest apparent amylose content) showed lower firmness. However, the product with higher apparent amylose content displayed higher firmness after $24 \mathrm{~h}$, suggesting a more rapid retrogradation.

One of the alternatives for reducing swelling of starch granules is by using an emulsifier which forms a film around the granule (SISWOYO \& MORITA, 2001; RICHARDSON et al, 2002). Emulsifiers form insoluble complexes with amylose, resulting in greater anti-aging effects and consequent extension of shelf life (JANG \& PYUN, 1996; GHANI et al, 1999).

From the characteristics determined with the RVA regarding final viscosity and tendency to retrogradation, it can be assumed that the cakes containing BPSF will have a extended shelf life due to the low retrogradation of the starch present in the final product.

The only blends that showed differences in granulometry $(\mathrm{P} \leq 0.05)$ were the ones containing $0 \%$ and $50 \%$ BPSF, i.e., the extreme points of the study. The texture evaluation of the cakes regarding firmness (A) and extensibility (B) in the first, seventh, and fifteenth days after baking are display in figure 2 .

Samples containing the highest proportions of BPSF (37.5\% and 50\%) initially did not differ from the others regarding firmness. However, firmness increased in the samples with higher proportions of rice flour over 15 days. Although, cakes prepared with blends with larger proportions of BPSF (37.5\% and 50\%) initially presented lower extensibility than the others, they presented the same extensibility than the 100\% rice flour after 15 days from baking. Thus, cakes prepared with the flour blends containing $37.5 \%$ or
$50 \%$ BPSF presented a more stable texture along the time of analysis.

SINGH et al. (2012) determined firmness and extensibility in gluten-free cakes added of corn bran and observed that texture was significantly affected by replacing corn flour by corn bran. Cakes freshly prepared with corn bran content higher than $20 \%$ resulted in greater firmness $(8.28 \mathrm{~N})$ when compared to the formulation with $100 \%$ rice flour $(7.56 \mathrm{~N})$. Extensibility was also significantly reduced with the addition of more than $10 \%$ of corn bran into the dough. In the present study, blends with higher BPSF content $(37.5 \%$ and $50 \%)$ resulted in cakes with firmness similar to those found by SINGH et al. (2012), but with greater extensibility, $60.73 \%$ versus $50.64 \%$ for cakes with $20 \%$ of corn bran. Thus, the results indicated that the addition of BPSF promoted better texture stability of the baked cakes, because the product was able to maintain its structural properties even at the end of the analysis time.

The chemical composition of cakes indicated that the BPSF increased the content of dietary fiber, which has a recognized digestive functionality. As shown in table 4, samples with the highest proportion of BPSF resulted in $3.80 \mathrm{~g}$ fibers $/ 100 \mathrm{~g}$ cake, against $1.62 \mathrm{~g}$ fibers $/ 100 \mathrm{~g}$ cake in products with $100 \%$ rice flour.

Both fiber and protein contents of BPSF cakes $(37.5 \%$ and $50 \%)$ were higher than the results reported by MAURICIO et al. (2012), who used several starch sources with low lipid levels in the formulation of gluten-free cakes (Table 4).Nearly $70 \%$ of the panelists liked (very much or moderately) the cakes developed in this study.

Flavor was rated as one of the main factors to determine the cakes purchase, while 


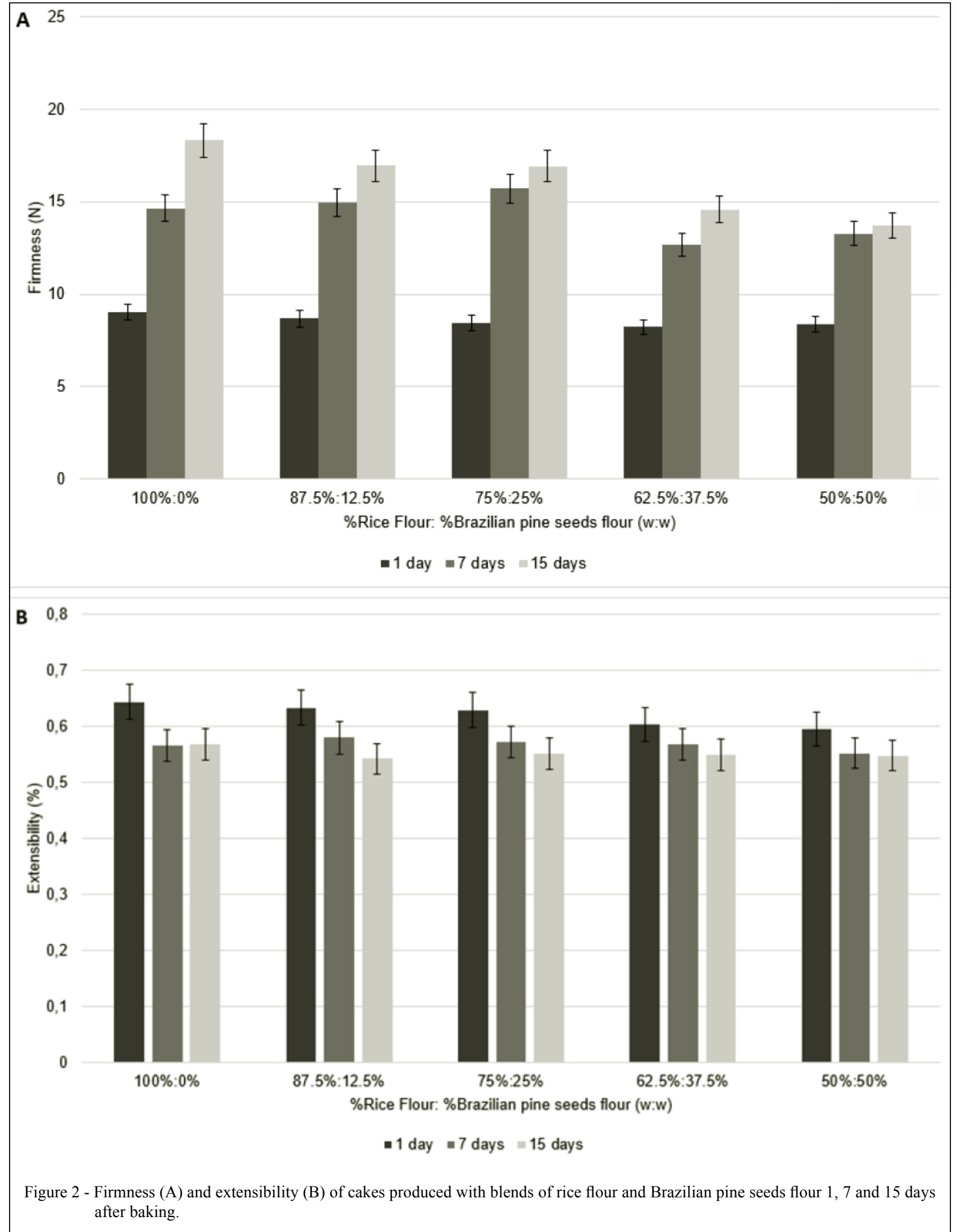

Ciência Rural, v.48, n.6, 2018. 
Table 4 - Chemical composition of cakes made with rice flour and Brazilian pine seeds flour blends compared to gluten-free cake prepared with rice flour, corn flour, potato starch and corn starch.

\begin{tabular}{|c|c|c|c|c|c|c|}
\hline $\begin{array}{l}\text { Rice flour: Brazilian } \\
\text { pine seeds flour ratio }\end{array}$ & $\begin{array}{l}\text { Moisture } \\
(\mathrm{g} / 100 \mathrm{~g})\end{array}$ & Ashes (g/100g) & $\begin{array}{c}\text { Total dietary } \\
\text { fiber }(g / 100 g)\end{array}$ & $\begin{array}{l}\text { Proteins } \\
(\mathrm{g} / 100 \mathrm{~g})\end{array}$ & Fats $(g / 100 g)$ & $\begin{array}{l}\text { Carbohydrates } \\
\quad(\mathrm{g} / 100 \mathrm{~g})\end{array}$ \\
\hline 100:00 & $25.04^{\mathrm{c}}$ & $2.50^{\mathrm{a}}$ & $1.62^{\mathrm{b}}$ & $5.87^{\mathrm{a}}$ & $17.32^{\mathrm{a}}$ & $47.65^{\mathrm{a}}$ \\
\hline $87.5: 12.5$ & $25.79^{\mathrm{b}}$ & $2.50^{\mathrm{a}}$ & $3.66^{\mathrm{ab}}$ & $5.74^{\mathrm{a}}$ & $17.22^{\mathrm{a}}$ & $45.09^{b c}$ \\
\hline $75: 25$ & $25.90^{\mathrm{b}}$ & $2.81^{\mathrm{a}}$ & $1.82^{\mathrm{ab}}$ & $6.05^{\mathrm{a}}$ & $16.61^{\mathrm{a}}$ & $46.81^{b}$ \\
\hline $62.5: 37.5$ & $27.29^{\mathrm{a}}$ & $2.49^{\mathrm{a}}$ & $3.58^{\mathrm{a}}$ & $5.77^{\mathrm{a}}$ & $15.72^{\mathrm{a}}$ & $45.15^{\mathrm{c}}$ \\
\hline $50: 50$ & $25.36^{\mathrm{bc}}$ & $2.66^{\mathrm{a}}$ & $3.8^{\mathrm{a}}$ & $5.7^{\mathrm{a}}$ & $16.30^{\mathrm{a}}$ & $46.18^{\mathrm{bc}}$ \\
\hline $\operatorname{Mix} 1^{\mathrm{a}}$ & NR & NR & 0.73 & 2.65 & 5.52 & 44.01 \\
\hline $\operatorname{Mix} 2^{\mathrm{a}}$ & NR & NR & 0.72 & 2.48 & 7.22 & 57.59 \\
\hline
\end{tabular}

${ }^{a}$ Data from Mauricio et al. (2012) - Mix 1: 35\% rice flour, 15\% corn flour, 35\% potato starch and 15\% corn starch; Mix 2: 40\% rice flour, $10 \%$ corn flour, $40 \%$ potato starch and $10 \%$ corn starch. ${ }^{*} \mathrm{NR}=$ Not reported. ${ }^{*}$ Means followed by the same letter in the same column do not differ according to the Tukey test at $5 \%$ probability.

price resulted in minor influence for the product purchase. The consideration of an ideal product, according to the panelists, is related to the maintenance of the structural properties of the cakes, without crumbling. The samples added of BPSF showed ideal crumbling characteristics in more than $50 \%$ of the tests (Figure 3). Conversely, the cake made from $100 \%$ rice flour received a rate of $43.15 \%$ for ideal acceptance and was considered crumbly by $34.31 \%$ of the panelists. Thus, BPSF reduced the sensory perception of crumbliness.

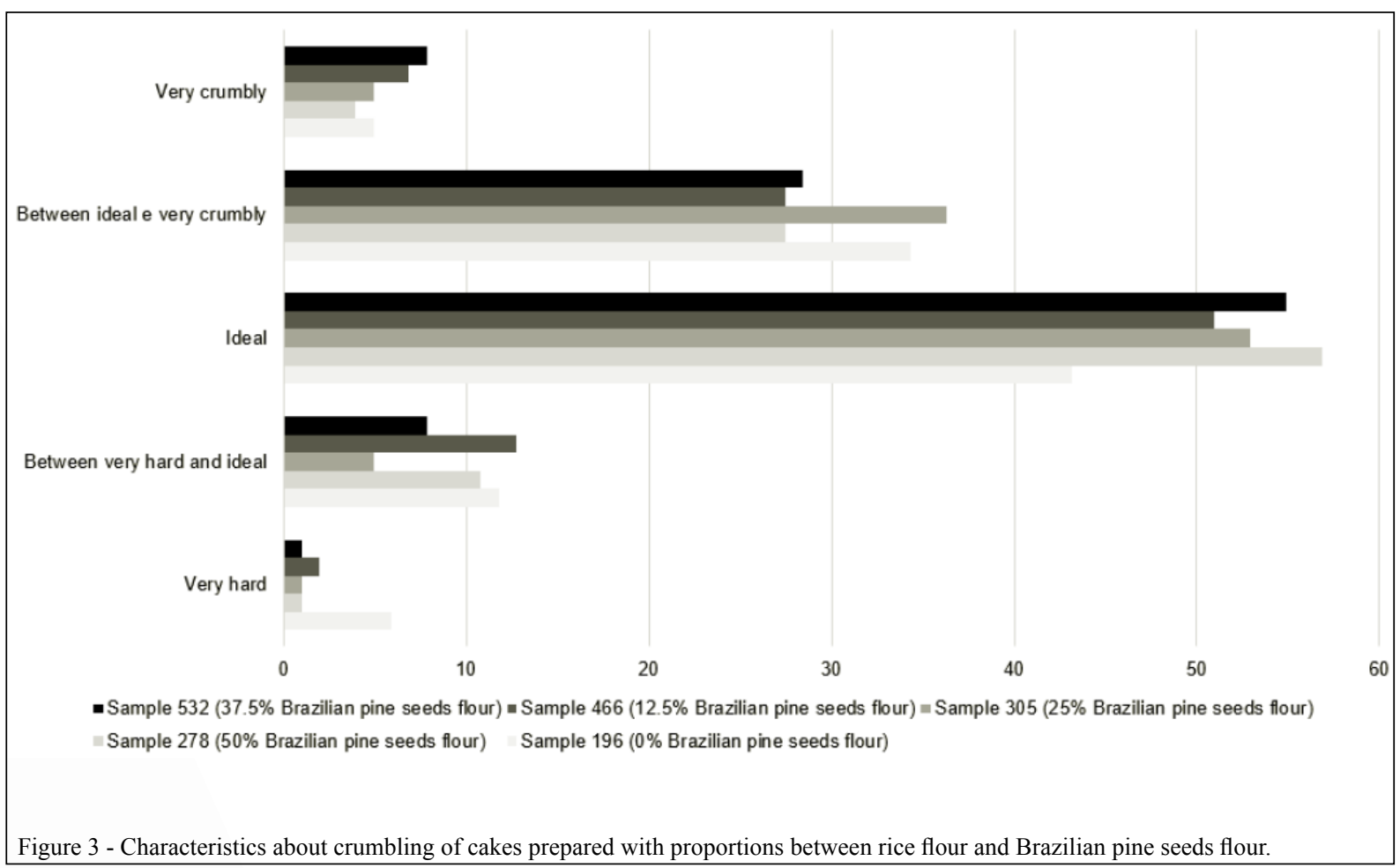

Ciência Rural, v.48, n.6, 2018. 
In the specific volume of the cakes, the samples showed value of $2.8 \pm 0.1 \mathrm{~cm}^{3 / g}$. Therefore, the products of each developed premix proved equivalents in terms of volume independent of the proportion of the applied flour. The Principal Component Analysis (PCA) allowed the grouping of treatments according to their physical-chemical characteristics and sensory acceptance. Each point in figure 4 represents the correlation between the consumer acceptance and the two first principal components (PCAs). Consumers correlated with at least one of the PCAs indicated differences in acceptance of samples. Most consumers stood in the central region of the graph.

Cluster analysis grouped consumers into two segments (95 and 7 consumers), whose concentrations were significantly higher between first and fourth quadrants (Figure 5). The individuals in segment two are located in opposite regions in relation to the samples, which indicated low acceptance of the products, while in segment 1 the consumers are located in the central region of the graph, representing a high acceptance level for most samples.
By analyzing the original data in isolation, consumers who were scattered in the graph differed from the others by the negative evaluation of the product, which indicated that the cakes had good consumer acceptance.

\section{CONCLUSION}

This study showed that it was possible to produce cakes with high scores of sensory acceptance, even when using $50 \%$ of Brazilian pine seed flour.

The cakes prepared with $50 \%$ or $37.5 \%$ of Brazilian pine seed flour provided substantial levels of dietary fiber $3.80 \mathrm{~g} / 100 \mathrm{~g}$ and $3.66 \mathrm{~g} / 100 \mathrm{~g}$, respectively, which represents more than double the fiber content of cakes prepared with rice flour only $(1.62 \mathrm{~g} / 100 \mathrm{~g})$. Addition of $50 \%$ or $37.5 \%$ of Brazilian pine seed flour in the flour blends did not change the dough viscosity and texture of the baked cakes, and promoted greater stability to the cake.

This research established an alternative product to the celiac market, since the Brazilian pine seed flour does not contain gluten. Furthermore, the exploitation of Araucaria angustifolia seeds might contribute to the preservation of this species.

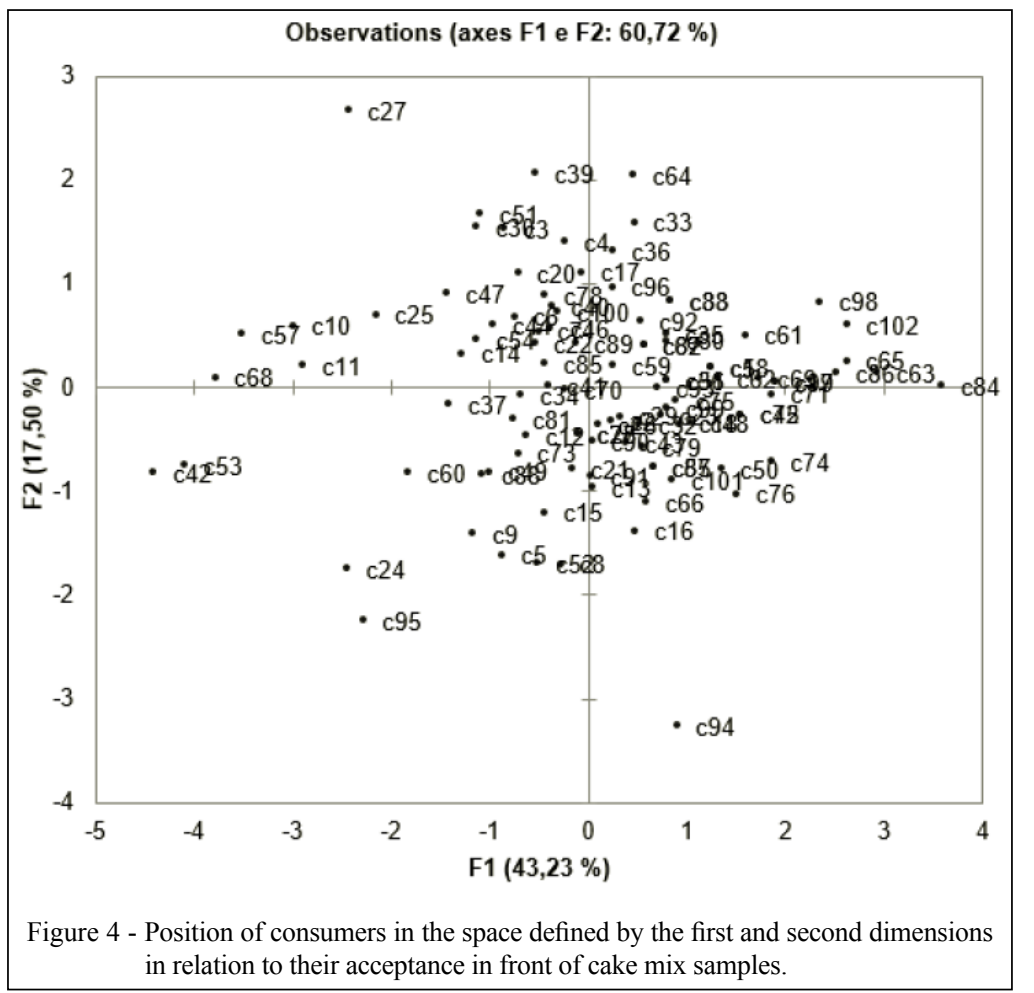

Ciência Rural, v.48, n.6, 2018. 


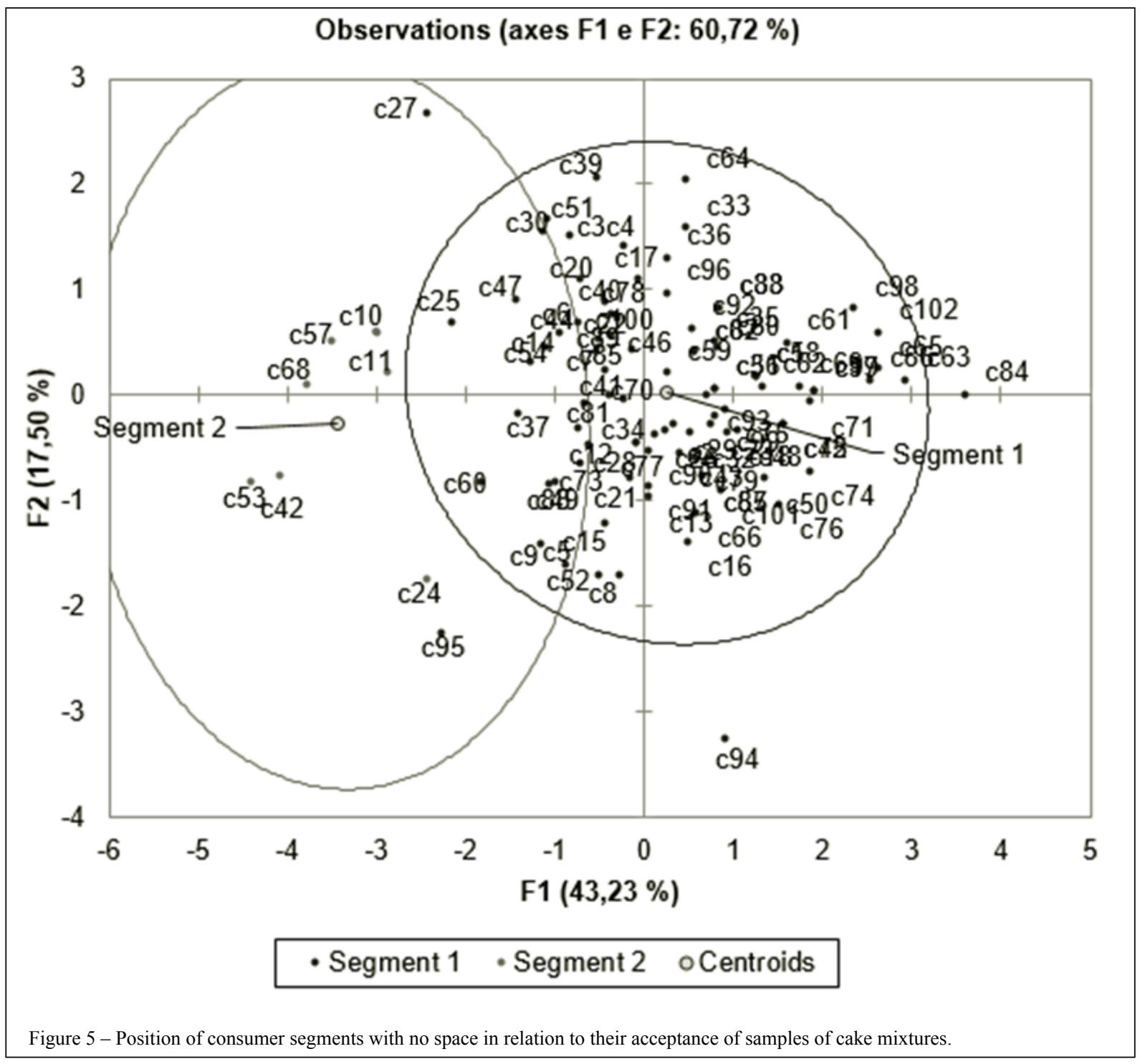

\section{ACKNOWLEDGEMENTS}

The authors would like to acknowledge the Graduation Program in Food Engineering of Federal University of Paraná (UFPR), Granolab Granotec do Brasil, Embrapa Florestas, Embrapa Rio de Janeiro, Industria Reunidas Coringa (Arapiraca, $\mathrm{AL})$, and the Department of Food Technology of University of Campinas (Unicamp).

\section{DECLARATION OF CONFLICTING INTERESTS}

The authors declare no conflict of interest. The founding sponsors had no role in the design of the study; in the collection, analyses, or interpretation of data; in the writing of the manuscript, and in the decision to publish the results.

\section{REFERENCES}

AACC - American Association of Cereal Chemists. Approved Methods, Saint Paul: AACC. 2. 10 $0^{\text {th }} \mathrm{ed}, 2000$.

ALONSO, L. B. \& MORAGA, C. B. Desarrollo de un Pan con Harina de Piñón de Araucarias in TACC. Development of a gluten-free bread with Brazilian pine seeds flour. 2014. Trabajo Final de Investigación. Instituto Universitario Fundación H.A. Barceló - Facultad de Medicina, Carrera de Nutrición.

AUGUSTO-RUIZ, W. et al. Charaterization of pregelatinized flour of whole rice produced from broken kemels. Vetor, Rio Grande, v.13, p.25-46, 2003. Available from: $<$ http://www.seer.furg.br/vetor/article/view/425>. Accessed:Apr. 9, 2016.

BRAZIL. Resolution RDC No. 54 of November 12, 2012. Approves the Technical Regulation on Complementary 
Nutrition Information. Issuing body: ANVISA - National Sanitary Surveillance Agency. Available from: <www.anvisa.gov. br>. Accessed: Feb. 12, 2018.

BRAZIL. Resolution RDC No. 359 of December 23, 2003. Approves the Technical Regulation on Nutritional Labeling of Packaged Foods. Issuing body: ANVISA - National Sanitary Surveillance Agency. Available from: <www.anvisa.gov.br>. Accessed: Feb. 12, 2018.

CAPELLA, A. C. V. Farinha de pinhão: composição e estabilidade do gel. Master's Dissertation. Universidade Federal do Paraná. 2008. Available from:<http://www.posalim.ufpr.br/ Pesquisa/dissertacoes.htm\#2010-2012>. Accessed: Mar. 31, 2018 .

CORNEJO, F. E. P. et al. Descascamento e secagem de pinhão (Araucaria angustifolia) para a obtenção de farinha. Embrapa Agroindústria de Alimentos. Comunicado técnico, 206. Brazil, 2014. Available from: <https://ainfo.cnptia.embrapa. br/digital/bitstream/item/117436/1/CT-206-4.pdf $>$. Accessed: May 01, 2016.

DELCOUR, J. A. et al. Fate of starch in food processing: from raw materials to final food products. Food Science and Technology, Belgium, v.1, p.87-111, April 2010. Available from: $\quad<$ http://www.annualreviews.org/doi/abs/10.1146/annurev. food.102308.124211>. Accessed: Mar. 28, 2016. doi: 10.1146/ annurev.food.102308.124211.

FENNEMA, et al. Food chemistry. Editora Artmed. 4 ${ }^{\mathrm{a}}$ Edição, Porto Alegre, 2010, 110-111p.

FERNG, L. et al. Physicochemical property and glycemic response of chiffon cakes with different rice flours. Food Hydrocolloids, v.53, p.172-179, February 2016. Available from: $\quad<$ http://www.sciencedirect.com/science/article/pii/ S0268005X15000818>. Accessed: May 26, 2016. doi:10.1016/j. foodhyd.2015.02.020

FERREIRA, V. L. et al. Sensory analysis of discriminative and affective tests. Campinas: SBCTA, 2000.

GORGÔNIO, C. M. S. et al. Macroscopic and physicochemical characterization of a sugarless and gluten-free cake enriched with fibers made from pumpkin seed (Cucurbita maxima, L.) flour and cornstarch. Ciência e Tecnologia de Alimentos, Campinas, v.31, p.109-118, Jan./March 2011. Available from: $<$ http://www.scielo.br/scielo.php?script=sci_arttext\&pid $=$ S0101-20612011000100015 $>$. Accessed: May 26, 2016. doi: 10.1590/S0101-20612011000100015.

JAN, R. et al. Physico-chemical, textural, sensory and antioxidant characteristics of gluten - Free cookies made from raw and germinated Chenopodium (Chenopodium album) flour. Food Science and Technology, v.71, p.281-287, September 2016. Available from: <http://www.sciencedirect.com/science/ article/pii/S0023643816301852>. Accessed: Apr. 26, 2016. doi: 10.1016/j.lwt.2016.04.001

JANG, J. K. \& PYUN, Y.R. Effect of moisture content on the melting of wheat starch. Starch, v.48, p.48-51, 1996. Available from: $<$ http://onlinelibrary.wiley.com/doi/10.1002/star.19960480204/ epdf $>$. Accessed: Jun. 18, 2016. doi: 10.1002/star.19960480204.
LI, B. et al. Just-About-Right and ideal scaling provide similar insights into the influence of sensory attributes on liking. Food Quality Preference, v.37, p.71-78, October 2014. Available from: <http:// www.sciencedirect.com/science/article/pii/S0950329314000767>. Accessed: May 26, 2016. doi: 10.1016/j.foodqual.2014.04.019.

MACFIE, H. J. et al. Designs to balance the effect of order of presentation and first-order carry-over effects in hall tests. Journal of Sensory Studies, v.4, p129-148, September 1989. Available from: <http://onlinelibrary.wiley.com/doi/10.1111/ j.1745-459X.1989.tb00463.x/pdf>. Accessed: Apr. 9, 2016. doi: 10.1111/j.1745-459X.1989.tb00463.X

MARIOTTI, et al. The role of corn starch, amaranth flour, pea isolate, and Psyllium flour on the rheological properties and the ultra structure of gluten-free doughs. Food Research International, v.42, p.963-975, October 2008. Available from: <http://www. sciencedirect.com/science/article/pii/S0963996909001240>. Accessed: Mar. 30, 2016. doi: 10.1016/j.foodres.2009.04.017.

MAURICIO, A. A. et al. Carrot cake with and without gluten: formulation and product acceptance. Agro@mbiente On-line, Boa Vista (Brazil), v.6, n.3, p.250-257, Sep./Dec. 2012. Available from: $<$ http://revista.ufrr.br/index.php/agroambiente/article/view/703>. Accessed: Apr. 9, 2016. doi: http://dx.doi.org/10.18227/19828470ragro.v6i3.703. (In Portuguese).

MORAIS, E. C. et al. Prebiotic gluten-free bread: Sensory profiling and drivers of liking. Food Science and Technology, v.55, p.248254, January 2014. Available from: <http://www.sciencedirect. com/science/article/pii/S0023643813002648>. Accessed: Jul. 18, 2016. doi: 10.1016/j.lwt.2013.07.014.

RAMOS, N. C. et al. Elaboration of a gluten-free cake mix. Alim. Nutr., Araraquara, v.23, n.1, p.33-38, Jan./Mar. 2012. Available from: <http://serv-bib.fcfar.unesp.br/seer/index.php/alimentos/article/ viewFile/1612/1202>. Accessed: Apr. 9, 2016.

RICHARDSON, G. et al. Microstructure of $\alpha$-crystalline emulsifiers and their influence on air incorporation in cake batter. Cereal Chemistry, v.79, p.546-55, July/August 2002. Available from: <http://aaccipublications.aaccnet.org/doi/ pdf/10.1094/CCHEM.2002.79.4.546>. Accessed: Jun. 13, 2016.

RUBIO-TAPIA, A. et al. Increased Prevalence and Mortality in Undiagnosed Celiac Disease. Gastroenterology, v.137, p.8893, July 2009. Available from: <http://www.sciencedirect.com/ science/article/pii/S001650850900523X>. Accessed: May 26, 2016. doi: 10.1053/j.gastro.2009.03.059

SINGH, M. et al. Effect of corn bran as dietary fiber addition on baking and sensory quality. Biocatalysis and Agricultural Biotechnology, v.1, p.348-352, October 2012. Available from: <http://www. sciencedirect.com/science/article/pii/S1878818112000333>. Accessed: Apr. 18, 2016. doi: 10.1016/j.bcab.2012.02.005.

SISWOYO, T. A. \& MORITA, N. Influence of acyl chain lengths in mono and diacyl-sn-glycerophosphatidylcholine on gelatinization and retrogradation of starch. Journal of Agricultural and Food Chemistry, v.49, p.4688-4693, September 2001. Available from: $<$ http://pubs.acs.org/doi/abs/10.1021/jf001357p >. Accessed: Apr. 9, 2016. doi: 10.1021/jf001357p.

XLSTAT. Sensory version (Windows). Addinsoft, France, 2014. 